\title{
Effect of bovine leukemia virus on bovine mammary epithelial cells
}

\author{
Lucia Martinez Cuesta ${ }^{\mathrm{a}, \mathrm{b}, *}$, Maria Victoria Nieto Farias ${ }^{\mathrm{c}}$, Pamela A. Lendez ${ }^{\mathrm{a}}$, \\ Raymond R.R. Rowland ${ }^{\mathrm{b}}$, Maureen A. Sheahan ${ }^{\mathrm{b}}$, Felipe A. Cheuquepán Valenzuela ${ }^{\mathrm{c}, \mathrm{d}}$, \\ Maia S. Marin ${ }^{c, d}$, Guillermina Dolcini ${ }^{\mathrm{a}}$, Maria Carolina Ceriani ${ }^{\mathrm{a}, *}$ \\ ${ }^{\text {a }}$ Laboratorio de Virología, Centro de Investigación Veterinaria de Tandil (CIVETAN, CONICET-CICPBA), Facultad de Cs. Veterinarias, UNCPBA, Pinto 399, Tandil \\ (7000) Pcia., Buenos Aires, Argentina \\ ${ }^{\mathrm{b}}$ Department of Diagnostic Medicine and Pathobiology, College of Veterinary Medicine, Kansas State University, Manhattan, KS, USA \\ ${ }^{\mathrm{c}}$ Consejo Nacional de Investigaciones Científicas y Técnicas (CONICET), Godoy Cruz 2290, C1033AAJ Buenos Aires, Argentina \\ d Área de Producción Animal, Estación Experimental Agropecuaria Balcarce, Instituto Nacional de Tecnología Agropecuaria (INTA), Ruta Nacional 226 Km 73.5 (7620), \\ Balcarce, Buenos Aires, Argentina
}

\section{A R T I C L E I N F O}

\section{Keywords:}

BLV

Mastitis

TLRs

Immune response

\begin{abstract}
A B S T R A C T
Bovine leukemia virus (BLV) is a retrovirus that infects cattle and is associated with an increase in secondary infections. The objective of this study was to analyze the effect of BLV infection on cell viability, apoptosis and morphology of a bovine mammary epithelial cell line (MAC-T), as well as Toll like receptors (TLR) and cytokine mRNA expression. Our findings show that BLV infection causes late syncytium formation, a decrease in cell viability, downregulation of the anti-apoptotic gene Bcl-2, and an increase in TLR9 mRNA expression. Moreover, we analyzed how this stably infected cell line respond to the exposure to Staphylococcus aureus (S. aureus), a pathogen known to cause chronic mastitis. In the presence of $S$. aureus, MAC-T BLV cells had decreased viability and decreased Bcl-2 and TLR2 mRNA expression. The results suggest that mammary epithelial cells infected with BLV have altered the apoptotic and immune pathways, probably affecting their response to bacteria and favoring the development of mastitis.
\end{abstract}

\section{Introduction}

Bovine leukemia virus (BLV) is a widely distributed retrovirus that infects cattle. This virus causes a persistent infection of B cells that, after some years, can lead to lymphosarcoma. However, most infected animals remain asymptomatic, and thus, the infection often goes unnoticed (Gillet et al., 2007). This lack of symptoms contributes to viral dissemination and might explain the high prevalence of the virus in dairy cattle (Kamińska et al., 2015; Maresca et al., 2015; Polat et al., 2017).

BLV is present worldwide, except for some countries in Europe, Australia and New Zealand, where it has been eradicated (Bartlett et al., 2014; Chethanond, 1999; Ryan, 2013; Maresca et al., 2015). This wide distribution and the high incidence among cattle make this virus an important concern for dairy production. The economic loss associated with BLV infection includes decreased milk production, higher incidence of secondary infections, and costs related to treatment and replacement of affected animals (Erskine et al., 2012; Kuczewski et al.,
2019; Da et al., 2015). Because of the impact of the virus on the immune system, BLV infection has been related to a higher incidence of mastitis (Florins et al., 2007; Frie and Coussens, 2015; Wellenberg et al., 2002). Mastitis, the inflammation of the mammary gland, which is mainly caused by infectious agents, is also an important problem for the dairy industry.

Bovine mammary epithelial cells play a crucial role in the onset of the innate immune response in mastitis. As the first barrier the immune response sets up in the mammary gland, the epithelium expresses Tolllike receptors (TLRs) that recognize certain patterns present in the pathogens and release cytokines that contribute to the recruitment and activation of effector immune cells (Rainard and Riollet, 2006). Pathogenic bacterial proteins are recognized mostly by TLR2 and TLR4, but also by other TLRs like TLR9 (Akira and Takeda, 2004); on the other hand, viral nucleic acids are mainly recognized by endosomal receptors TLR3, TLR7/8, and TLR9. The activation of these receptors induces the release of proinflammatory cytokines and interferons (IFN) such as IFN$\beta$ and INF- $\gamma$. In BLV infected animals with low proviral load, IFN- $\beta$

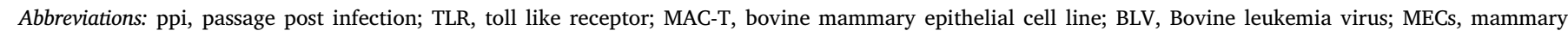
epithelial cells

* Corresponding authors.

E-mail addresses: lmartinez@vet.unicen.edu.ar (L. Martinez Cuesta), cceriani@vet.unicen.edu.ar (M.C. Ceriani). 
mRNA expression is higher than in animals with high proviral load, suggesting that this cytokine plays a role in viral suppression (Nieto Farias et al., 2016).

Bovine mammary epithelium responds differently to the various pathogens that can infect it. For example, the presence of heat-inactivated Escherichia coli increases the expression of TLR2 and TLR4, TNF- $\alpha$, IL-6, IL8, and IL-1 $\beta$ in bovine mammary epithelial cells. However, incubation of these cells with heat-inactivated $S$. aureus produces a lesser and delayed increase in TLR2, TNF- $\alpha$, IL-6, IL8 and IL$1 \beta$ and no variation in TLR4 expression (Fu et al., 2013).

Until now, studies that analyze the effect of BLV on mastitis incidence have had inconclusive results. BLV has been found in bovine mammary gland epithelial cells from infected cows (Buehring et al., 1994) and the feasibility of infection has been proved in vitro using a bovine mammary epithelial cell (MEC) line (Martinez Cuesta et al., 2018). Due to the role that MEC play during the first response to mastitis, it is important to analyze the effect that BLV infection has on the cells' capacity to detect pathogens and release inflammatory cytokines. Taken together, a further study of the effect of the virus on bovine mammary epithelial cells (MECs) would help elucidate the relationship between BLV infection and mastitis susceptibility.

We have previously shown that bovine MECs are susceptible to infection with BLV. In this work, we demonstrate that the infection is productive. We analyze the effects of the virus on cell morphology, viability, apoptosis, and its impact on the mammary epithelium innate immune response. Moreover, we evaluate how BLV infection affects the bovine mammary epithelium response to heat inactivated $S$. aureus.

\section{Materials and methods}

\subsection{Cell lines and culture conditions}

MAC-T (Huynh et al., 1991) and MAC-T stably infected with BLV (MAC-T BLV)(Martinez Cuesta et al., 2018) were cultured in Modified Eagle's medium (MEM) supplemented with $10 \%$ fetal bovine serum (MIDSCI, Valley Park, MO, USA) and $1 \mu \mathrm{g} / \mathrm{mL}$ hydrocortisone (SigmaAldrich, Saint Louis, MO, USA) at $37{ }^{\circ} \mathrm{C}$ with $5 \% \mathrm{CO}_{2}$.

\subsection{Reinfection assay}

MAC-T cells were seeded in 24 well plates and grown to $80 \%$ confluency. At that point, cells were incubated with MAC-T BLV supernatant from a confluent monolayer at 19 passage post infection (ppi), previously filtered through a $22 \mu \mathrm{m}$ filter unit (Millipore Sigma, USA). After three days, cells were fixed and analyzed by Indirect Fluorescence Immunoassay (IFI).

\subsection{Indirect Fluorescent Immunoassay (IFI) to detect viral protein p24}

Cells were washed twice with PBS and fixed with 80\% acetone for 5 min. Cells were incubated with 1:500 anti-BLV-p24 monoclonal antibody (NIH AIDS Reagent Program) (Buehring et al., 1994) in PBS containing 5\% goat serum (PBS-GS) for $1 \mathrm{~h}$. After that, cells were washed three times with PBS and incubated with 1:400 Alexa Fluor ${ }^{\mathrm{TM}} 488$ goat anti-mouse IgG (Invitrogen for Thermo Fisher Scientific, Waltham, MA, USA) in PBS-GS for $1 \mathrm{~h}$. After three washes with PBS, cells were stained for 5 min with 1:3000 propidium iodide (Invitrogen for Thermo Fisher Scientific, Waltham, MA, USA) in PBS-GS. After washing, $100 \mu \mathrm{L}$ of PBS was added to each well, and the cells were analyzed with a fluorescent microscope (EVOS XL Cell Imaging System, Thermo Fisher Scientific, Waltham, MA, USA).

\subsection{Cell morphology analysis}

MAC-T and MAC-T BLV cells were cultured until 100\% confluence and photographed with the microscope EVOS XL Cell Imaging System
(Thermo Fisher Scientific, Waltham, MA, USA).

\subsection{The MTT viability assay}

Ten thousand cells were seeded in each well of a 96 well plate and incubated $48 \mathrm{~h}$ at $37^{\circ} \mathrm{C}$. The MTT assay estimates cell viability by measuring the reduction of soluble tetrazolium salt to insoluble formazan crystals by the dehydrogenase metabolism of live cells (Morgan, 1998). Twenty microliters of 3-(4,5-dimethyl-2thiazolyl)-2,5-diphenyl$2 \mathrm{H}$-tetrazolium bromide (MTT) solution $(5 \mathrm{mg} / \mathrm{mL}$ ) (Sigma-Aldrich, Saint Louis, MO, USA) were added to each well. After $4 \mathrm{~h}$ incubation, the plate was centrifuged at $2000 \mathrm{rpm}$ for $2 \mathrm{~min}$, and the formazan crystals were resuspended using $200 \mu \mathrm{L}$ of DMSO (MP Biomedicals, Santa Ana, ca. USA). The absorbance at $570 \mathrm{~nm}$ was determined using a Microplate Spectrophotometer (Epoch, BioTek, Winooski, VT, USA). Results were expressed as percent viability relative to the non-infected MAC-T cells. The MAC-T mean OD was considered $100 \%$ viability and MAC-T BLV OD was relativized to that. The experiment was repeated three times, with four technical replicates each time. The statistical analysis was performed in Infostat using ANOVA test to determine whether the viability was affected with the different passages after BLV infection. There was no statistical difference, hence the data were analyzed with a $t$-test

\subsection{Quantification of cytokine and TLR mRNA expression}

Cells were harvested with Trizol $^{\circledR}$ (Thermo Fisher Scientific, Waltham, MA, USA), and total RNA extraction was performed using Direct-zol $^{\mathrm{TM}}$ RNA MiniPrep Plus (ZymoResearch, Irvine, CA, USA). RNA concentration and purity were determined in a NanoDrop 2000 Spectrophotometer (Thermo Fisher Scientific, Waltham, MA, USA) and its integrity was analyzed using Agilent 2100 Bioanalyzer (Agilent, Santa Clara, CA, USA). To remove any possible contamination with genomic DNA, $1 \mu \mathrm{g}$ of each RNA sample was treated with RNase-free DNase I (Thermo Fisher Scientific, Waltham, MA, USA) according to the manufacturer's instructions.

Reverse transcription of the mRNA was carried out using iScript ${ }^{\mathrm{TM}}$ cDNA Synthesis Kit (Bio-Rad, Hercules, California, USA) following the manufacturer's instructions. Relative-qPCR was performed using the master mix SsoAdvanced ${ }^{\mathrm{TM}}$ Universal SYBR ${ }^{\circledR}$ Green Supermix (Bio-Rad, Hercules, California, USA) in a final volume of $20 \mu \mathrm{L}$. The amplification and detection processes were carried out in a StepOnePlus ${ }^{\mathrm{TM}}$ Real-Time PCR System (Applied Biosystems, Foster City, CA, USA). Two technical replicates and negative controls for cDNA synthesis were included in all cases. Primers used for amplification are listed in Supplementary Table 1. Target gene expression was normalized to that of the endogenous gene, GAPDH. Data were analyzed using LinregPCR and FgStatisitcs. Statistically significant differences were considered when $\mathrm{p}<0.05$.

\subsection{Bacterial stimulation assay}

For bacterial stimulating experiments, MAC-T and MAC-T BLV cells growing in a 6 well plate were incubated for 3,6 and $18 \mathrm{~h}$ with $200 \mu \mathrm{L}$ of a heat-inactivated suspension of $S$. aureus ATCC 29213 (OD =0.3). Heat inactivation was carried out at $60^{\circ} \mathrm{C}$ for $1 \mathrm{~h}$.

\section{Results}

\subsection{MAC-T BLV actively produce infective virus}

MAC-T BLV supernatant contained viral particles that were capable of infecting other cells. As shown in Fig. 1, three days after the infection of MAC-T cells with MAC-T BLV supernatant, we were able to detect infection by IFI. 
PROPIDIUM IODIDE
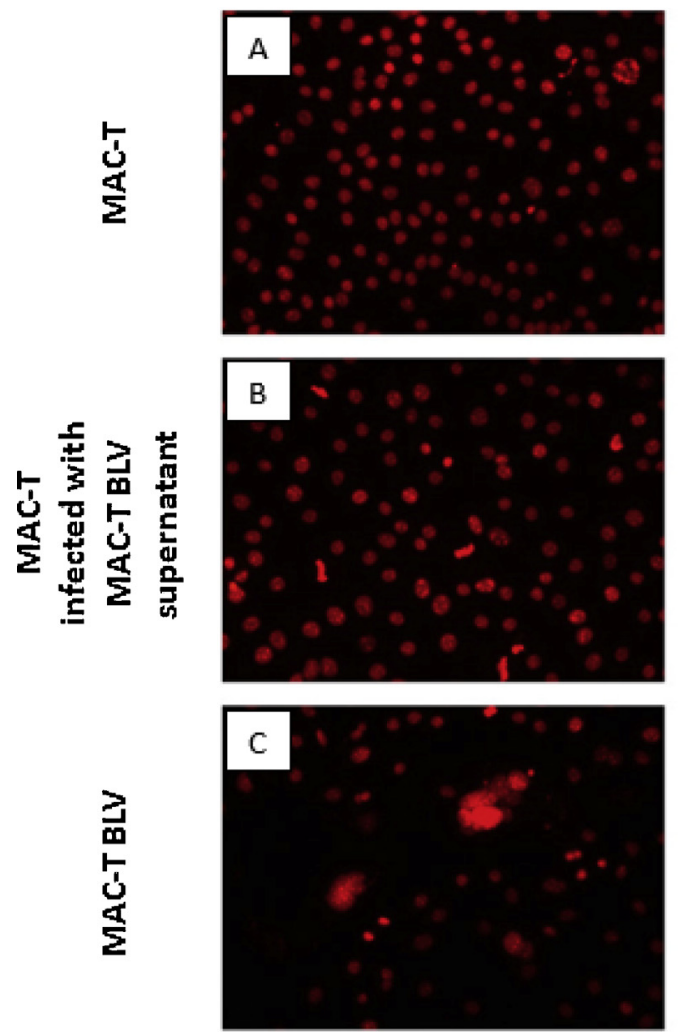

ANTI-P24
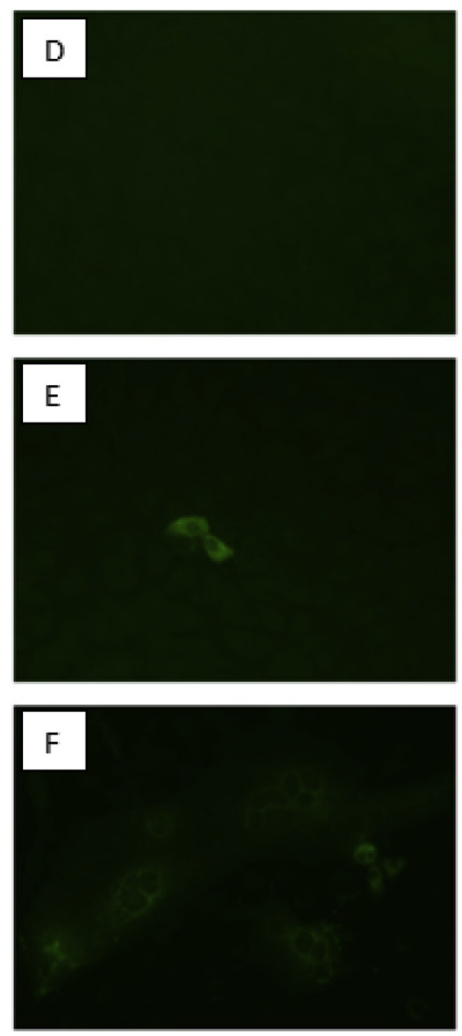

MERGE
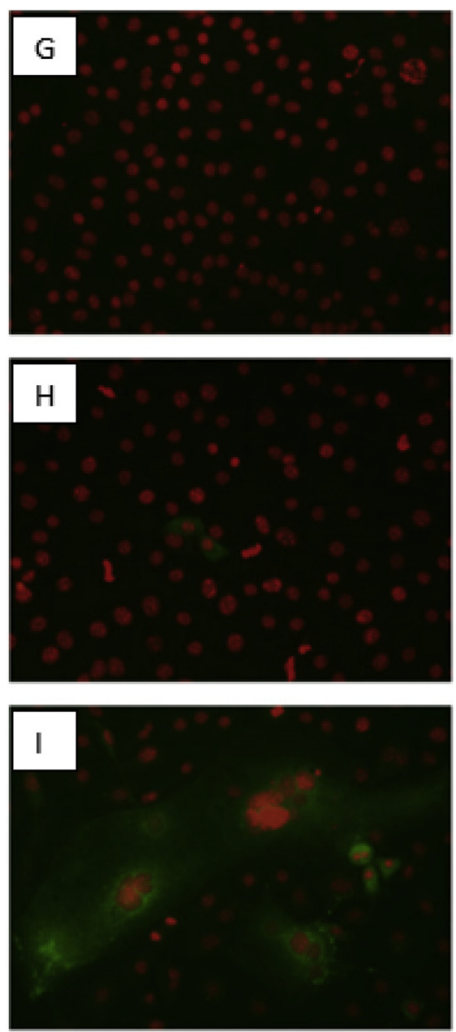

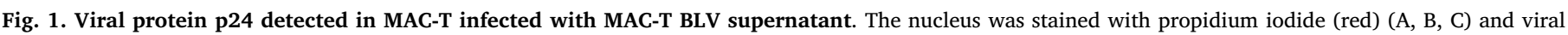
protein was immune-stained with a monoclonal antibody against BLV-p24 protein (green) (D, E, F) to obtain merged images (G, H, I). Amplification $10 \times$.

\subsection{Effect of BLV on MAC-T cells morphology, cell proliferation, and apoptosis}

MAC-T BLV cells at 3 passage post-infection (ppi) started to show cytopathic effect characterized by the formation of cellular syncytium. Infected cells presented multiple nuclei and are larger than the uninfected MAC-T cells (Fig. 2).

The effect of stable BLV infection on bovine MEC survival was analyzed. MAC-T BLV had $72.18 \%$ survival compared to the control cells, MAC-T ( $\mathrm{p}<0.0001$ ). This decrease in viability was present in all passages up to $43 \mathrm{ppi}$, and there was no statistical difference between passages (Fig. 3).

To assess the effect of the virus on apoptosis, we measured pro- and anti-apoptotic gene expression by RT-qPCR (Fig. 4). The anti-apoptotic Bcl-2 gene was downregulated 0.34-fold $(\mathrm{p}=0.04)$ in BLV infected cells compared to uninfected MAC-T cells. Another pro- and antiapoptotic gene, Bax and Bcl-xl, respectively, were not modulated by the infection ( $\mathrm{p}=0.37$ and 0.05 , respectively).

\subsection{Effect of BLV on cytokine and TLRS MRNA expression}

IFNs and pro-inflammatory cytokines, together with TLR mRNA expression, were determined by RT-qPCR. TLR9 was the only gene modulated by the infection; expression of this receptor was highly increased in BLV infected cells (FC $=61.9$-fold, $p<0.00001)$. Expression of other cytokines (IL-6, IFN $\beta$, and IFN $\gamma$ ) and TLRs (TLR2, TLR3, TLR4, and TLR8) was not affected by BLV infection ( $\mathrm{p}>0.05$, data not shown).

\subsection{Effect of BLV on MAC-T response to $S$. aureus}

After $3 \mathrm{~h}$ of incubation with heat-inactivated $S$. aureus suspension,
MAC-T BLV cell viability decreased $15.38 \%$ compared to the non-infected MAC-T cells $(\mathrm{p}=0.008)$. Viability continued to decrease with increased time of exposure to $S$. aureus reaching $25.90 \%(\mathrm{p}=0.003)$ and $26.46 \%(\mathrm{p}=0.03)$ after 6 and $18 \mathrm{~h}$ of exposure, respectively (Fig. 5).

Anti-apoptotic Bcl-2 mRNA expression was analyzed at different time points after incubation with $S$. aureus. Bcl-2 mRNA expression decreased in MAC-T BLV cells $0.55(\mathrm{p}=0.10), 0.29(\mathrm{p}=0.04)$ and 0.59 -fold $(\mathrm{p}=0.08)$ after 3,6 and $18 \mathrm{~h}$ of exposure, respectively, compared to MAC-T cells (Fig. 6A).

The expression of TLR2 mRNA in the presence of $S$. aureus was analyzed. TLR2 mRNA in MAC-T BLV was downregulated 0.28-fold $(\mathrm{p}=0.03)$ after $3 \mathrm{~h}$ of incubation with $S$. aureus, 0.24 -fold $(\mathrm{p}=0.04)$ after $6 \mathrm{~h}$ and, 0.58 -fold $(\mathrm{p}=0.08)$ after $18 \mathrm{~h}$ (Fig. $6 \mathrm{~B})$.

\section{Discussion}

We have previously demonstrated that BLV can stably infect the bovine mammary epithelial cell line, MAC-T (Martinez Cuesta et al., 2018). In this study, we show that this infection is productive, which means that MAC-T BLV cells release infective viral particles. This result has a great impact on our knowledge about BLV vertical transmission. In the early days of research on BLV it was assumed that BLV only infected lymphocytes present in the mammary gland, and therefore those were the only cells responsible for transmitting the infection. The discovery of cow's milk MECs containing BLV p24 capsid protein (Buehring et al., 1994) raised the question of whether MECs could transmit the virus through milk. Our results reported here provide experimental in vitro proof that intercellular transmission from BLV-infected MECs is possible and infective virions from MECs might contribute to mother to calf transmission. Previous studies detected viral DNA in milk from BLV infected animals, but it has never been analyzed 

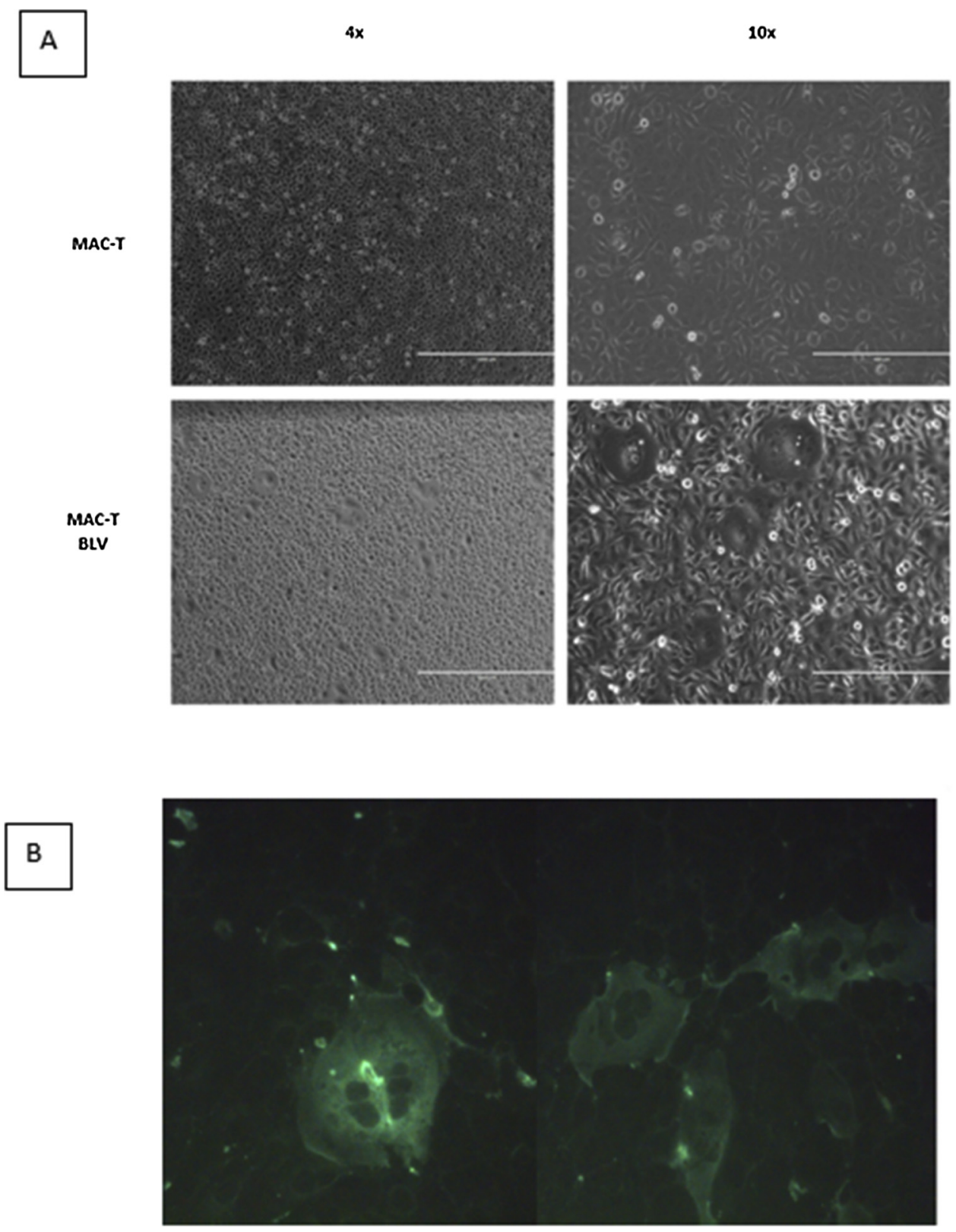

Fig. 2. MAC-T BLV cells have cytopathic effect at passage 3 post infection ( 3 ppi). A) Cell morphology analyzed by bright field microscopy. Scale bar $4 \mathrm{x}$ : $1000 \mu \mathrm{m}$. Scale bar $10 \times: 400 \mu \mathrm{m}$. B) IFI to visualize cell morphology of BLV infected cells at 3 ppi. Viral protein p24 was stained with a monoclonal p24 antibody and the secondary antibody, Alexa Fluor ${ }^{\mathrm{TM}} 488$. Amplification $20 \times$.

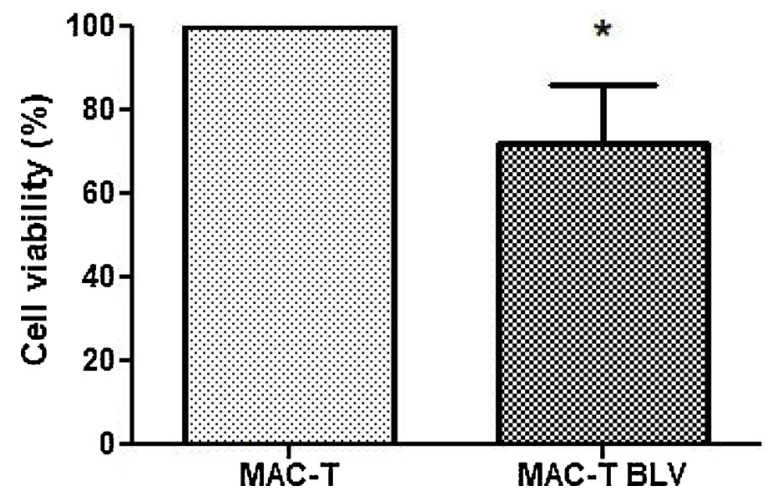

Fig. 3. Cell viability analyzed by MTT. MAC-T BLV cell viability percentage relative to MAC-T cell survival, considered as $100 \%$ viability. An asterisk (*) indicates statistically significant differences $(\mathrm{p}<0.05)$ with MAC-T. whether that virus came from lymphocytes or mammary epithelial cells (Gutiérrez et al., 2015, 2014). Although BLV infection in vivo in B lymphocytes is not associated with active viral production, little is known about bovine mammary epithelial infection in vivo and whether it actively releases virus or not. In fact, viral particles have been detected in mammary tissue isolated from cows naturally infected with BLV undergoing subclinical mastitis (Yoshikawa et al., 1997). The infection of the mammary epithelial cells has been reported for other viruses like HIV and HTLV-1 (Southern and Southern, 1998; Toniolo et al., 1995). In those cases, the mammary epithelium plays an important role in virus transmission (Dorosko and Connor, 2010). These similarities support the role of mammary epithelial cells in BLV transmission. Furthermore, it would be interesting to study whether other epithelial cells such as the intestinal epithelium are susceptible to BLV infection and if they play a role in virus transmission, as it occurs in HIV and HTLV-1 (Fujino and Nagata, 2000; John-Stewart et al., 2004).

When infected by BLV, MAC-T cells show cytopathic effect 


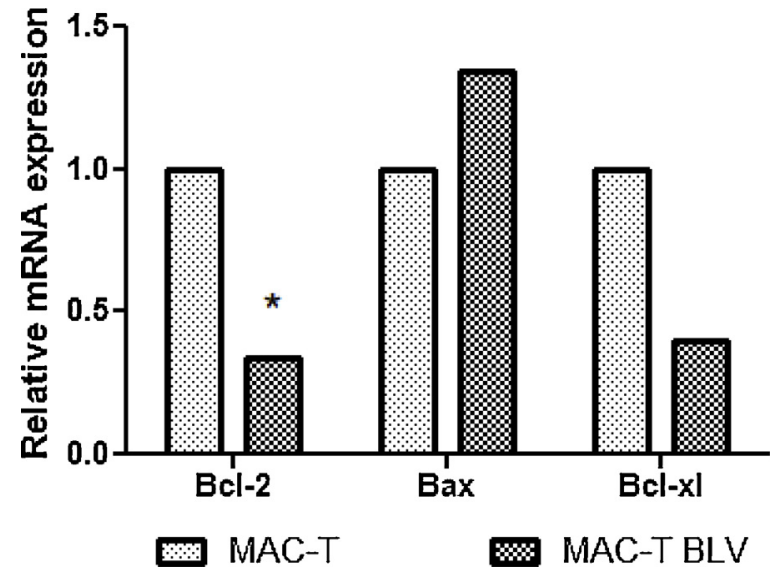

Fig. 4. Anti-apoptotic Bcl-2 gene is downregulated in MAC-T BLV cells. Pro and anti-apoptotic genes mRNA relative expression levels in MAC-T and MAC-T BLV cells were determined by RT-qPCR. An asterisk (*) indicates statistically significant differences $(\mathrm{p}<0.05)$ compared to the uninfected control (MAC-T).

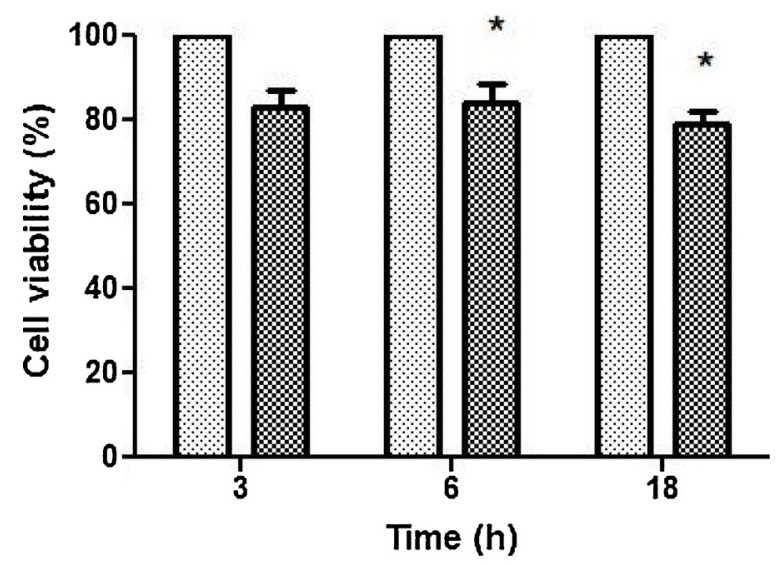

2 MAC-T MAC-T BLV

Fig. 5. BLV infection decreases cell viability in MAC-T cells exposed to inactivated $S$. aureus. The viability percentage of MAC-T BLV cells is expressed compared to MAC-T cell survival when both cell lines were exposed to heat-inactivated $S$. aureus suspensions. An asterisk (*) indicates statistically significant differences $(\mathrm{p}<0.05)$.

characterized by syncytium formation. BLV capacity to fuse somatic cells has been previously demonstrated in several cell lines including CC81, bat lung cells, and bovine embryonic spleen, among others (Graves and Ferrer, 1976; Graves and Jones, 1981). Cell fusion caused by a virus can be divided into early and late polykaryocytosis. The former appears during the first hours after inoculation, is caused by structural components of the virus, presumably from the envelope, and can occur in the absence of infection. On the other hand, late polykaryocytosis occurs days after the inoculation and is believed to be caused by cellular changes induced by the virus, suggesting that infection is required to produce this type of cell fusion (Ferrer and Cabradilla, 1978). In MAC-T cells, BLV infection induces syncytia formation at 3 ppi. This late polykaryocytosis also confirms that the MAC$\mathrm{T}$ cells are susceptible to BLV infection.

Host cells activate apoptosis as a mechanism to avoid virus replication (Nainu et al., 2017). There are two ways of starting the apoptotic process. The intrinsic pathway is induced by different intracellular stress conditions and ends with the mitochondrial outer membrane permeabilization, which is regulated by proteins from the BCL-2 family. The extrinsic pathway is activated by extracellular stress
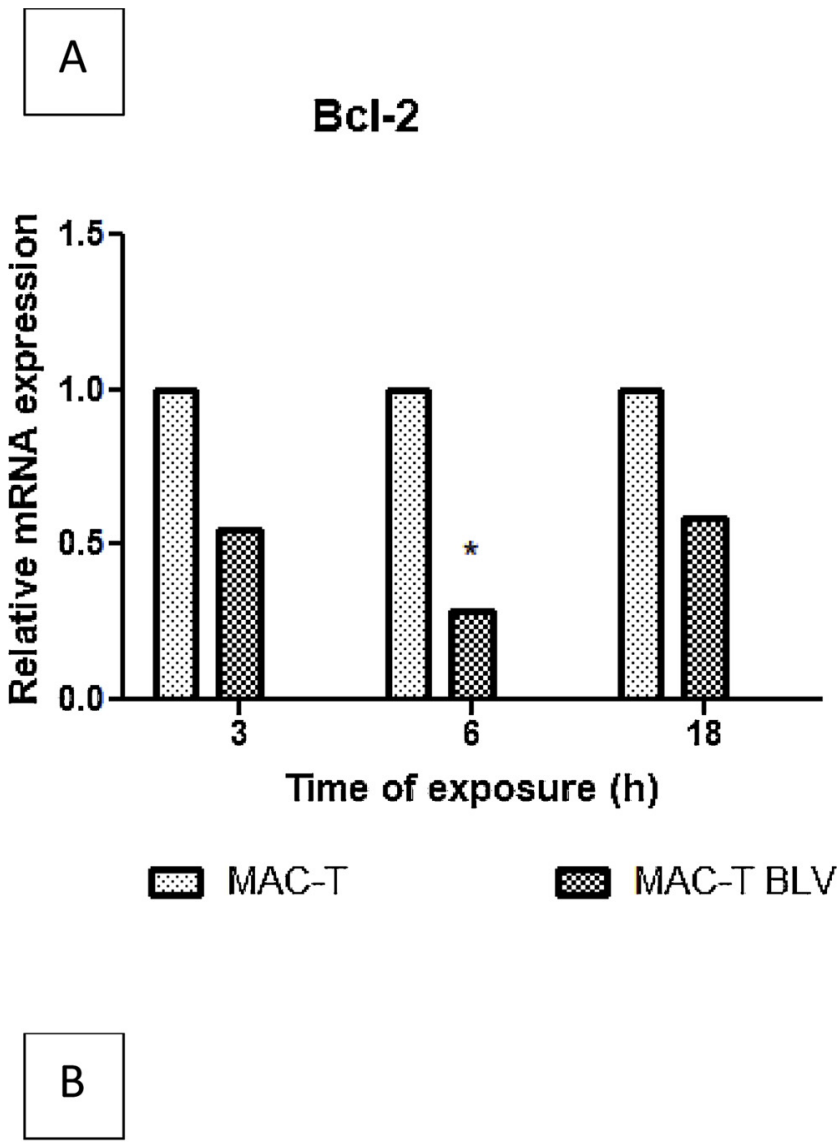

TLR2

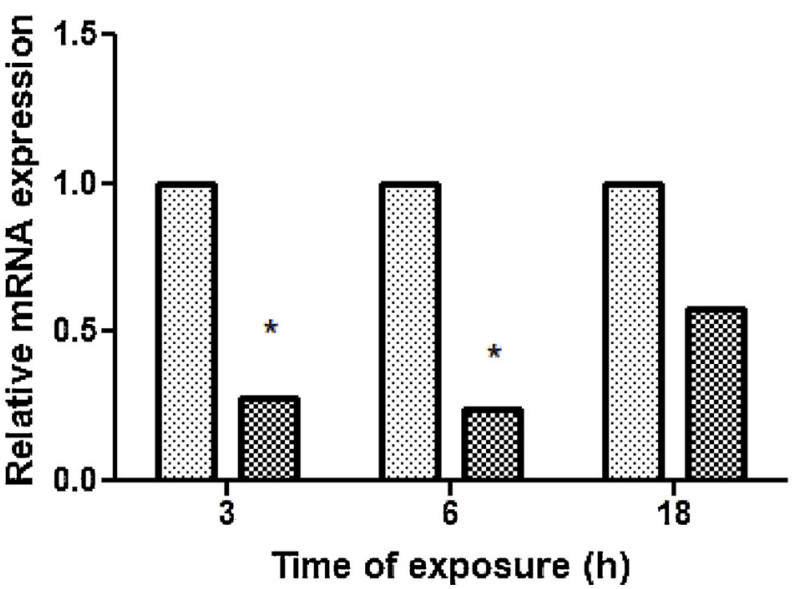

MAC-T $\approx$ MAC-T BLV

Fig. 6. Bcl-2 and TLR2 relative mRNA expression decreases when BLV infected-bovine mammary epithelial cells are exposed to heat-inactivated S. aureus. Relative mRNA expression levels in MAC-T BLV compared to MAC-T cells were determined by RT-qPCR. One asterisk $(*)$ indicates statistical significance $(\mathrm{p}<0.05)$.

conditions that are sensed through the death receptors belonging to the tumor necrosis factor (TNF) family (Zhou et al., 2017). Most of the studies regarding the effect of BLV on B-lymphocytes conclude that the virus reduces the apoptotic rate and increases the viability and proliferation rate (Debacq et al., 2006; Dequiedt et al., 1997; Erskine et al., 2011; Nieto Farias et al., 2018). However, there is barely any 
information about the effect of BLV on these parameters when the virus infects epithelial cells. Our results show that bovine MECs infected with BLV are less viable and express less anti-apoptotic Bcl-2 mRNA than uninfected epithelial cells, consistent with previous studies in bovine MECs transfected with BLV that showed a reduced population doubling time (Motton and Buehring, 2003).

Many factors could be contributing to the observed decrease in cell viability and the anti-apoptotic Bcl-2 expression in MAC-T BLV cells. First, it could be caused by the death of bystander cells. It is known that other retroviruses, such as HIV and HTLV, induce apoptosis of bystander cells (Doitsh et al., 2010; Finkel et al., 1995; Rivera-Walsh et al., 2001). Additionally, we have previously reported an increase in TNF- $\alpha$ expression in MAC-T BLV cells (Martinez Cuesta et al., 2018), which could be activating the extrinsic pathway of apoptosis. Moreover, it has been reported in HIV infection that syncytium formation is associated with apoptosis and that chronically infected cells induce apoptosis in non-infected cells (Gougeon et al., 1993; Laurent-Crawford et al., 1991). Both conditions are present in MAC-T BLV cells and could be contributing to the decrease in viability.

Also, the response to pathogens is different between lymphocytes and epithelial cells exposed to the same stimulus. As a mechanism to control infections, epithelial cells tend to decrease their viability when infected (Maarouf et al., 2018; Nainu et al., 2017; Ramage et al., 2017). Similar to what we have observed in MAC-T BLV, E. coli infection causes a decrease in Bcl-2 expression without changes in Bcl-xl expression in bovine mammary epithelial cells (Long et al., 2001). Interestingly, it has also been demonstrated that human mammary epithelial cells have decreased cell viability when infected in vitro with the H1N1 influenza virus (Paquette et al., 2015).

The decrease in cell viability could also have implications in milk production. It has been reported a decreased production of casein and other milk proteins in bovine mammary epithelial cells transfected with a plasmid containing the complete BLV sequence (Motton and Buehring, 2003).

It is well known that primary viral infections increase the susceptibility to bacterial infections by affecting the epithelial barriers, favoring bacterial attachment, or modulating the immune response (Blevins et al., 2014; Patel et al., 1992; Robinson et al., 2014; Sajjan et al., 2008). In this scenario, the reduction in cell viability caused by BLV infection in bovine mammary epithelial cells could damage the epithelium integrity and, thus, favor the development of bacterial infections. Moreover, BLV infection affects milk neutrophils phagocytic capacity, which could also favor bacterial proliferation (Della Libera et al., 2015).

We analyzed the effect of the virus in the mammary epithelial transcription of TLRs and cytokines. While mRNA production of most TLRs and cytokines were unaffected by BLV infection, TLR9 mRNA expression was significantly increased in BLV infected cells. This receptor recognizes unmethylated $\mathrm{CpG}$ dinucleotides in DNA, and its increased expression has been described in peripheral blood lymphocytes (PBMCs) from high proviral load BLV infected cows (Nieto Farias et al., 2016), as well as in PBMCs infected with bovine alpha-herpesvirus (Marin et al., 2014).

TLR2 mRNA expression showed a slight decrease in BLV infected cells; however, the difference was not statistically significative. Nevertheless, this decrease in TLR2 expression may have a biological significance since this TLR contributes to the detection of a wide range of pathogens, and it was effectively modulated after exposure of BLVinfected cells to bacteria. It has been shown that, when treated with heat-inactivated bacteria, bovine mammary epithelial cells from animals genetically predisposed to a lower incidence of mastitis express more TLR2, TNF- $\alpha$, IL-1 $\beta$, IL- 6 and IL- 8 than cells from animals associated with a higher risk of mastitis (Griesbeck-Zilch et al., 2009). Additionally, downregulation of TLR2 and TLR4 expression has been described in cases of naturally occurring influenza A infection, which may increase the incidence of secondary infections in humans (Lee et al., 2013). Taken all together, we believe that this decrease in TLR2 expression in mammary epithelial cells could impair the recognition of secondary pathogens that are mainly detected by that receptor.

To corroborate if BLV infected cells have altered the capacity to respond to bacteria trough TLR2, we compared the cell viability, antiapoptotic Bcl-2 mRNA expression, and TLR2 mRNA expression of the cells incubated with heat-inactivated $S$. aureus, one of the main pathogens causing subclinical and chronic mastitis in cattle and mainly recognized trough TLR2. The decrease in cell viability and anti-apoptotic gene Bcl-2 mRNA expression compared to the uninfected MAC-T support our other results that BLV infected MECs are more susceptible to the presence of bacteria, which could lead to a greater incidence of mastitis. Moreover, after exposure $(3$ and $6 \mathrm{~h}$ ) to heat-inactivated $S$. aureus, MAC-T BLV cells express less TLR2 mRNA than MAC-T cells. This suggests that BLV infection in the mammary epithelium reduces the capacity of these cells to recognize the presence of pathogens, and it might be at least in part through modulation of TLR2.

\section{Conclusion}

This is the first report that analyzes BLV infection of bovine mammary epithelial cells, demonstrating that BLV can productively infect bovine mammary epithelial cells in vitro, induce a cytopathic effect, and decrease the viability. Moreover, we have shown that BLV infected cells express less TLR2 mRNA when exposed to heat-inactivated $S$. aureus, suggesting that BLV could impair bacterial recognition through this receptor and thus, favor the development of certain bacterial infections. Future epidemiologic research on cattle herds needs to be done to determine if the presence of the virus in the mammary gland increases the incidence of mastitis.

\section{Funding}

The project was partially supported by the Agencia Nacional de Promoción Científica y Tecnológica (ANPCyT)PICT 2016-4408, PICT 2017-0378 and the Consejo Nacional Investigaciones Científicas y Tecnológicas (CONICET) from Argentina.

\section{Declaration of Competing Interest}

The authors declared no potential conflicts of interest concerning the research, authorship, publication of this article, and/or financial and personal relationships that could inappropriately influence this work.

\section{Acknowledgments}

The monoclonal anti-p24 antibody from Dr. G. Buehring was obtained through the AIDS Reagent Program, Division of AIDS, NIAID, NIH. We thank the Molecular Biology Core supported by CVM-KSU and Dr. Juan $J$ Loor from the University of Illinois for kindly sharing the MAC-T cell line.

\section{Appendix A. Supplementary data}

Supplementary material related to this article can be found, in the online version, at doi:https://doi.org/10.1016/j.virusres.2019.197678.

\section{References}

Akira, S., Takeda, K., 2004. Toll-like receptor signalling. Nat. Rev. Immunol. 4, 499-511. https://doi.org/10.1038/nri1391.

Bartlett, P.C., Sordillo, L.M., Byrem, T.M., Norby, B., Grooms, D.L., Swenson, C.L., Zalucha, J., Erskine, R.J., 2014. Options for the control of bovine leukemia virus in dairy cattle. J. Am. Vet. Med. Assoc. 244, 914-922. https://doi.org/10.2460/javma. 244.8.914.

Blevins, L.K., Wren, J.T., Holbrook, B.C., Hayward, S.L., Swords, W.E., Parks, G.D., 
Alexander-Miller, M.A., 2014. Coinfection with Streptococcus pneumoniae negatively modulates the size and composition of the ongoing influenza-specific CD8 ${ }^{+}{ }^{\mathrm{T}}$ cell response. J. Immunol. 193, 5076-5087. https://doi.org/10.4049/jimmunol. 1400529.

Buehring, G.C., Kramme, P.M., Schultz, R.D., 1994. Evidence for bovine leukemia virus in mammary epithelial cells of infected cows. Lab. Invest. 71, 359-365.

Chethanond, U.-S., 1999. The Epidemiology of Enzootic Bovine Leukosis in Dairy Cattle in New Zealand. Massey University.

Debacq, C., Gillet, N., Asquith, B., Sanchez-Alcaraz, M.T., Florins, A., Boxus, M. Schwartz-Cornil, I., Bonneau, M., Jean, G., Kerkhofs, P., Hay, J., Théwis, A., Kettmann, R., Willems, L., 2006. Peripheral blood B-cell death compensates for excessive proliferation in lymphoid tissues and maintains homeostasis in bovine leukemia virus-infected sheep. J. Virol. 80, 9710-9719. https://doi.org/10.1128/JVI. 01022-06.

Della Libera, A.M.M.P., De Souza, F.N., Batista, C.F., Santos, B.P., De Azevedo, L.F.F., Ramos Sanchez, E.M., Diniz, S.A., Silva, M.X., Haddad, J.P., Blagitz, M.G., 2015. Effects of bovine leukemia virus infection on milk neutrophil function and the milk lymphocyte profile. Vet. Res. 46, 1-8. https://doi.org/10.1186/s13567-014-0125-4.

Dequiedt, F., Hanon, E., Kerkhofs, P., Pastoret, P.P., Portetelle, D., Burny, A., Kettmann, R., Willems, L., 1997. Both wild-type and strongly attenuated bovine leukemia viruses protect peripheral blood mononuclear cells from apoptosis. J. Virol. 71, 630-639.

Doitsh, G., Cavrois, M., Lassen, K.G., Zepeda, O., Yang, Z., Santiago, M.L., Hebbeler, A.M., Greene, W.C., 2010. Abortive HIV infection mediates CD4 T cell depletion and inflammation in human lymphoid tissue. Cell 143, 789-801. https://doi.org/10.1016/ j.cell.2010.11.001.

Dorosko, S.M., Connor, R.I., 2010. Primary human mammary epithelial cells endocytose HIV-1 and facilitate viral infection of CD4 + T lymphocytes. J. Virol. 84, 10533-10542. https://doi.org/10.1128/JVI.01263-10.

Erskine, R.J., Bartlett, P.C., Byrem, T.M., Render, C.L., Febvay, C., Houseman, J.T., 2012. Association between bovine leukemia virus, production, and population age in Michigan dairy herds. J. Dairy Sci. 95, 727-734. https://doi.org/10.3168/jds.2011 4760.

Erskine, R.J., Corl, C.M., Gandy, J.C., Sordillo, L.M., 2011. Effect of infection with bovine leukosis virus on lymphocyte proliferation and apoptosis in dairy cattle. Am. J. Vet. Res. 72, 1059-1064. https://doi.org/10.2460/ajvr.72.8.1059.

Ferrer, J.F., Cabradilla, C.D., 1978. The phenomenon of polykaryocytosis induced by BLV in mixed cultures: specificity, mechanisms and application to the diagnosis of BLV infection in cattle. Ann. Rech. Vet. 9, 721-728.

Finkel, T.H., Tudor-Williams, G., Banda, N.K., Cotton, M.F., Curiel, T., Monks, C., Baba, T.W., Ruprecht, R.M., Kupfer, A., 1995. Apoptosis occurs predominantly in bystander cells and not in productively infected cells of HIV- and SIV-infected lymph nodes. Nat. Med. 1, 129-134.

Florins, A., Gillet, N., Asquith, B., Boxus, M., Burteau, C., Twizere, J., Urbain, P., Vandermeers, F., Debacq, C., Sanchez-Alcaraz, M.T., Schwartz-cornil, I., Kerkhofs, P., Jean, G., Théwis, A., Hay, J., Mortreux, F., Wattel, E., Reichert, M., Burny, A., Kettmann, R., Bangham, C., Willems, L., 2007. Cell dynamics and immune response to BLV infection: a unifying model. Front. Biosci. (Schol. Ed.) 12, 1520-1531. https:// doi.org/10.2741/2165.

Frie, M.C., Coussens, P.M., 2015. Bovine leukemia virus: a major silent threat to proper immune responses in cattle. Vet. Immunol. Immunopathol. 163, 103-114. https:// doi.org/10.1016/j.vetimm.2014.11.014.

Fu, Y., Zhou, E., Liu, Z., Li, F., Liang, D., Liu, B., Song, X., Zhao, F., Fen, X., Li, D., Cao, Y., Zhang, X., Zhang, N., Yang, Z., 2013. Staphylococcus aureus and Escherichia coli elicit different innate immune responses from bovine mammary epithelial cells. Vet. Immunol. Immunopathol. 155, 245-252. https://doi.org/10.1016/J.VETIMM.2013. 08.003 .

Fujino, T., Nagata, Y., 2000. HTLV-I transmission from mother to child. J. Reprod. Immunol.

Gillet, N., Florins, A., Boxus, M., Burteau, C., Nigro, A., Vandermeers, F., Balon, H., Bouzar, A.B., Defoiche, J., Burny, A., Reichert, M., Kettmann, R., Willems, L., 2007. Mechanisms of leukemogenesis induced by bovine leukemia virus: prospects for novel anti-retroviral therapies in human. Retrovirology 4, 1-32. https://doi.org/10 1186/1742-4690-4-18.

Gougeon, M.L., Laurent-Crawford, A.G., Hovanessian, A.G., Montagnier, L., 1993. Direct and indirect mechanisms mediating apoptosis during HIV infection: contribution to in vivo CD4 T cell depletion. Semin. Immunol. 5, 187-194. https://doi.org/10.1006/ smim.1993.1022.

Graves, D.C., Ferrer, J.F., 1976. In Vitro Transmission and Propagation of the Bovine Leukemia Virus in Monolayer Cell Cultures.

Graves, D.C., Jones, L.V., 1981. Early syncytium formation by bovine leukemia virus. J. Virol.

Griesbeck-Zilch, B., Osman, M., Kühn, C., Schwerin, M., Bruckmaier, R.H., Pfaffl, M.W., Hammerle-Fickinger, A., Meyer, H.H.D., Wellnitz, O., 2009. Analysis of key molecules of the innate immune system in mammary epithelial cells isolated from markerassisted and conventionally selected cattle. J. Dairy Sci. 92, 4621-4633. https://doi. org/10.3168/jds.2008-1954.

Gutiérrez, G., Alvarez, I., Merlini, R., Rondelli, F., Trono, K., 2014. Dynamics of Perinatal Bovine Leukemia Virus Infection. pp. 1-5. https://doi.org/10.1186/1746-614810-82.

Gutiérrez, G., Lomonaco, M., Alvarez, I., Fernandez, F., Trono, K., 2015. Characterization of colostrum from dams of BLV endemic dairy herds. Vet. Microbiol. 177, 366-369. https://doi.org/10.1016/j.vetmic. 2015.03.001.

Huynh, H.T., Robitaille, G., Turner, J.D., 1991. Establishment of bovine mammary epithelial cells (MAC-T): an in vitro model for bovine lactation. Exp. Cell Res. 197, 191-199.
John-Stewart, G., Mbori-Ngacha, D., Ekpini, R., Janoff, E.N., Nkengasong, J., Read, J.S., Van de Perre, P., Newell, M.-L., Ghent IAS Working Group on HIV in Women

Children, 2004. Breast-feeding and transmission of HIV-1. J. Acquir. Immune Defic. Syndr. 35, 196-202.

Kamińska, M., Ciszewski, T., Łopacka-Szatan, K., Miotła, P., Starosławska, E., 2015. Breast cancer risk factors. Prz. Menopauzalny 14, 196-202. https://doi.org/10.5114/ pm.2015.54346.

Kuczewski, A., Hogeveen, H., Orsel, K., Wolf, R., Thompson, J., Spackman, E., van der Meer, F., 2019. Economic evaluation of 4 bovine leukemia virus control strategies for Alberta dairy farms. J. Dairy Sci. 102, 2578-2592. https://doi.org/10.3168/jds. 2018-15341.

Laurent-Crawford, A.G., Krust, B., Muller, S., Rivlire, Y., Rey-Cuilli, M.-A., Bichet, J.-M., Montagnier, L., Lnstitut, Hovanessian', Pasteur, A.G., 1991. The cytopathic effect of HIV is associated with apoptosis. Virology.

Lee, N., Wong, C.K., Hui, D.S.C., Lee, S.K.W., Wong, R.Y.K., Ngai, K.L.K., Chan, M.C.W., Chu, Y.J., Ho, A.W.Y., Lui, G.C.Y., Wong, B.C.K., Wong, S.H., Yip, S.P., Chan, P.K.S., 2013. Role of human Toll-like receptors in naturally occurring influenza A infections. Influenza Other Respi. Viruses 7, 666-675. https://doi.org/10.1111/irv.12109.

Long, E., Capuco, A.V., Wood, D.L., Sonstegard, T., Tomita, G., Paape, M.J., Zhao, X., 2001. Escherichia coli induces apoptosis and proliferation of mammary cells. Cell Death Differ. 8, 808-816. https://doi.org/10.1038/sj.cdd.4400878.

Maarouf, M., Rai, K.R., Goraya, M.U., Chen, J.-L., 2018. Immune ecosystem of virusinfected host tissues. Int. J. Mol. Sci. 19. https://doi.org/10.3390/ijms19051379.

Maresca, C., Costarelli, S., Dettori, A., Felici, A., Iscaro, C., Feliziani, F., 2015. Enzootic bovine leukosis: report of eradication and surveillance measures in Italy over an 8year period (2005-2012). Prev. Vet. Med. 119, 222-226. https://doi.org/10.1016/j. prevetmed.2015.02.024.

Marin, M.S., Quintana, S., Faverín, C., Leunda, M.R., Odeón, A.C., Pérez, S.E., 2014. Tolllike receptor activation and expression in bovine alpha-herpesvirus infections. Res. Vet. Sci. 96, 196-203. https://doi.org/10.1016/J.RVSC.2013.11.015.

Martinez Cuesta, L., Nieto Farias, M.V., Lendez, P.A., Barone, L., Pérez, S.E., Dolcini, G.L., Ceriani, M.C., 2018. Stable infection of a bovine mammary epithelial cell line (MACT) with bovine leukemia virus (BLV). Virus Res. 256, 11-16. https://doi.org/10. 1016/j.virusres.2018.07.013.

Morgan, D.M., 1998. Tetrazolium (MTT) assay for cellular viability and activity. Methods Mol. Biol. 79, 179-183.

Motton, D.D., Buehring, G.C., 2003. Bovine leukemia virus alters growth properties and casein synthesis in mammary epithelial cells. J. Dairy Sci. 86, 2826-2838. https:// doi.org/10.3168/jds.S0022-0302(03)73880-6.

Nainu, F., Shiratsuchi, A., Nakanishi, Y., 2017. Induction of apoptosis and subsequent phagocytosis of virus-infected cells as an antiviral mechanism. Front. Immunol. 8, 1220. https://doi.org/10.3389/fimmu.2017.01220.

Nieto Farias, M.V., Lendez, P.A., Marin, M., Quintana, S., Martínez-Cuesta, L., Ceriani, M.C., Dolcini, G.L., 2016. Toll-like receptors, IFN- $\gamma$ and IL-12 expression in bovine leukemia virus-infected animals with low or high proviral load. Res. Vet. Sci. 107, 190-195. https://doi.org/10.1016/j.rvsc.2016.06.016.

Nieto Farias, M.V., Nogueira De Souza, F., Anahí Lendez, P., Martínez-Cuesta, L., Santos, K.R., Maria, A., Paiva, M., Libera, D., Ceriani, C., Dolcini, G.L., 2018. Title: lymphocyte proliferation and apoptosis of lymphocyte subpopulations in bovine leukemia virus-infected dairy cows with high and low proviral load. Vet. Immunol. Immunopathol. https://doi.org/10.1016/j.vetimm.2018.10.012.

Paquette, S.G., Banner, D., Huang, S.S.H., Almansa, R., Leon, A., Xu, L., Bartoszko, J., Kelvin, D.J., Kelvin, A.A., 2015. Influenza transmission in the mother-infant dyad leads to severe disease, mammary gland infection, and pathogenesis by regulating host responses. PLoS Pathog. 11, e1005173. https://doi.org/10.1371/journal.ppat. 1005173.

Patel, J., Faden, H., Sharma, S., Ogra, P.L., 1992. Effect of respiratory syncytial virus on adherence, colonization and immunity of non-typable Haemophilus influenzae: implications for otitis media. Int. J. Pediatr. Otorhinolaryngol. 23, 15-23. https://doi. org/10.1016/0165-5876(92)90075-Z.

Polat, M., Takeshima, S.-N., Aida, Y., 2017. Epidemiology and genetic diversity of bovine leukemia virus. Virol. J. 14, 209. https://doi.org/10.1186/s12985-017-0876-4.

Rainard, P., Riollet, C., 2006. Innate immunity of the bovine mammary gland. Vet. Res. 37, 369-400. https://doi.org/10.1051/vetres:2006007.

Ramage, G., Lappin, D.F., Millhouse, E., Malcolm, J., Jose, A., Yang, J., Bradshaw, D.J., Pratten, J.R., Culshaw, S., 2017. The epithelial cell response to health and disease associated oral biofilm models. J. Periodontal Res. Suppl. 52, 325-333. https://doi. org/10.1111/jre.12395.

Rivera-Walsh, I., Waterfield, M., Xiao, G., Fong, A., Sun, S.C., 2001. NF-kappaB signaling pathway governs TRAIL gene expression and human T-cell leukemia virus-I Tax-induced T-cell death. J. Biol. Chem. 276, 40385-40388. https://doi.org/10.1074/jbc. C100501200.

Robinson, K.M., McHugh, K.J., Mandalapu, S., Clay, M.E., Lee, B., Scheller, E.V., Enelow, R.I., Chan, Y.R., Kolls, J.K., Alcorn, J.F., 2014. Influenza A Virus Exacerbates Staphylococcus aureus Pneumonia in Mice by Attenuating Antimicrobial Peptide Production. J. Infect. Dis. 209, 865-875. https://doi.org/10.1093/infdis/jit527.

Ryan, Diane, 2013. Eradication of Enzootic Bovine Leucosis in National Dairy Herd. Posted Flock Herd.

Sajjan, U., Wang, Q., Zhao, Y., Gruenert, D.C., Hershenson, M.B., 2008. Rhinovirus disrupts the barrier function of polarized airway epithelial cells. Am. J. Respir. Crit. Care Med. 178, 1271-1281. https://doi.org/10.1164/rccm.200801-136OC.

Southern, Š.O., Southern, P.J., 1998. Persistent HTLV-I Infection of Breast Luminal Epithelial Cells: A Role in HTLV Transmission? Virology 241, 200-214. https://doi. org/10.1006/viro.1997.8978.

Toniolo, A., Serra, C., Conaldi, P.G., Basolo, F., Falcone, V., Dolei, A., 1995. Productive HIV-1 infection of normal human mammary epithelial cells. AIDS 9, 859-866. 
Wellenberg, G.J., Van Der Poel, W.H.M., Van Oirschot, J.T., 2002. Viral infections and bovine mastitis: a review. Vet. Microbiol. 88, 27-45. https://doi.org/10.1016/S03781135(02)00098-6.

Da, Yang, Shanks, Roger D., J.A.S, H.A.L, 2015. Milk and fat yields decline in bovine leukemia virus-infected Holstein cattle with persistent lymphocytosis. J. Am. Vet. Med. Assoc. 13, 914-922. https://doi.org/10.2903/j.efsa.2015.
Yoshikawa, H., Xie, B., Oyamada, T., Hiraga, a, Yoshikawa, T., 1997. Detection of bovine leukemia viruses (BLV) in mammary tissues of BLV antibody-positive cows affected by subclinical mastitis. J. Vet. Med. Sci. 59, 301-302. https://doi.org/10.1292/jvms. 59.301.

Zhou, X., Jiang, W., Liu, Z., Liu, S., Liang, X., 2017. Virus infection and death receptormediated apoptosis. Viruses 9. https://doi.org/10.3390/v9110316. 